\title{
Notes
}

\section{Tribal Courts' Failure to Protect Native American Women: A Reevaluation of the Indian Civil Rights Act}

\section{Carla Christofferson}

Congress has always exercised control over Native American ${ }^{1}$ peoples through its plenary powers. ${ }^{2}$ In 1968 , that control took the form of the Indian Civil Rights Act (ICRA). ${ }^{3}$ The ICRA represents a congressional decision to limit Native American sovereignty by setting forth an Indian Bill of Rights that applies to Native American tribes. ${ }^{4}$ It is Congress' effort to protect individuals from tribal abuses. By designing a special Indian Bill of Rights, ${ }^{5}$ Congress

1. This Note uses the terms Native American, American Indian, and Indian interchangeably. This usage is not meant to offend any individual's or group's preference, but to reflect the variety of terms used in federal Indian law.

2. U.S. CONST. art. I, \& 8, cl. 3 ("The Congress shall have Power ... [t]o regulate Commerce with foreign Nations, among the several States, and with the Indian Tribes."); see also Lone Wolf v. Hitchcock, 187 U.S. 553 (1903) (Congress has plenary power to abrogate provisions of Indian treaty).

The plenary doctrine has been sharply criticized as embracing racial and cultural prejudice against Native Americans and as implying that they are inferior and require guardianship by Congress. These criticisms notwithstanding, courts are bound by the Supreme Court's rulings that Congress may limit the sovereign rights of Indian tribes. Red Lake Band of Chippewa Indians v. Ross Swimmer, 740 F. Supp. 9, 11 (D.D.C. 1990).

3. Pub. L. No. 90-284, 82 Stat. 77 (codified at 25 U.S.C. $\$ \S 1301-41$ (1988)).

4. Before the ICRA, courts followed Talton v. Mayes, 163 U.S. 376 (1896), which stated that the Bill of Rights does not apply to Indian tribes.

5. The Act includes most of the Bill of Rights verbatim. 25 U.S.C. $\S 1302$ (1988). 
recognized that Native American tribes were distinct sovereigns, but it placed limits on how they could exercise such sovereignty. ${ }^{6}$

Although the central purpose of the ICRA is to "protect individual Indians from arbitrary and unjust actions of tribal governments," the Supreme Court limited this protection in Santa Clara Pueblo v. Martinez by ruling that habeas corpus is the only mechanism of judicial review provided by the ICRA. ${ }^{8}$ In providing no remedy for civil rights violations, the Santa Clara ruling has left Native American women virtually paralyzed within a system that subordinates women. ${ }^{9}$

This Note argues that an expansion of the ICRA is necessary to protect Native American women from discriminatory actions by their tribes. One Native American woman has stated: "My only crime is being born a female. I want the same rights as the men-the right to vote for a chief and the right to live on the reservation."10 Women who are discriminated against because of gender-biased tribal membership codes suffer both financially and psychologically. They no longer receive federal Indian benefits, such as annuities from the tribe, access to education and health programs, and housing. ${ }^{11}$ Moreover, they suffer the loss of their cultural identity, because they lose the right to live on the reservation with their family and friends. ${ }^{12}$

Part I of this Note examines the limitations on Native American sovereignty and the passage of the 1968 Indian Civil Rights Act, in which Congress endorsed the concept of limited tribal sovereignty. Part II examines the Supreme Court's attempt to establish firm sovereignty boundaries in Santa Clara Pueblo v. Martinez. ${ }^{13}$ This Note goes on to argue that the denial of a federal forum in Santa Clara renders the ICRA inadequate to protect the rights of Native American individuals. Part III describes how the ICRA in its present form fails to safeguard the rights of Native American women. It argues that an expansion of the ICRA is needed to remedy the gender discrimination facing women

6. Native Americans have never enjoyed sovereignty in the fullest sense. Sovereignty is defined, in part, as "[t]he power to do everything in a state without accountability." BLACK'S LAW DICTIONARY 1396 (6th ed. 1990). Native American tribal sovereignty is limited by what Congress is willing to tolerate. United States v. Wheeler, 435 U.S. 313, 323 (1978) (tribes have right to punish their members). Tribal sovereignty may be divested either by federal law or when it is inconsistent with the overriding interests of the federal government. Washington v. Confederated Tribes of the Colville Indian Reservation, 447 U.S. 134, 160-61 (1980) (state can tax Indians making purchases on reservation other than their own).

7. S. REP. No. 841 , 90th Cong., Ist Sess. 6 (1967).

8. 436 U.S. $49,69-70$ (1978).

9. Judith Resnik, Dependent Sovereigns: Indian Tribes, States, and the Federal Courts, 56 U. CHI. L. REv. 671, 702 (1989).

10. Joe Volz, Pocahontas' Legacy Law on Mixed Marriages Threatens Tribe's Future, CHI. TRIB., Apr. 9, 1989, at N7 (quoting Kim Taylor, a Native American woman who, unlike men in her tribe, is not allowed to bring her white spouse to live on reservation).

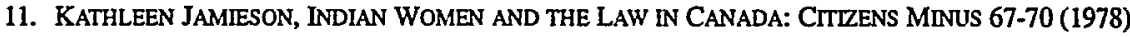
(discussing economic problems in both Canada and United States).

12. Pam Paul, Report prepared for the Native Women's Association of Canada (1989) (unpublished manuscript on file with author). The practice of denying women the right to live on the reservation also occurs in the United States. See Volz, supra note 10.

13. 436 U.S. 49 (1978). 
within tribal systems. Finally, Part IV proposes an amendment to the Indian Civil Rights Act designed to empower the Native American women in their struggle to secure equal rights within the tribal system. The amendment provides specific gender protection to Native American women within their tribe and gives the women a forum in which to bring their grievances.

\section{The INDIAN CIVIL Rights ACt: TOWARD TRIBAL SOVEREIGNTY}

In 1968, Congress passed the Indian Civil Rights Act. ${ }^{14}$ The ICRA recognized the tribes' sovereignty and their inherent right to govern the Native American peoples, but it stated that tribes would still be subject to constitutional guidelines resembling the Bill of Rights. ${ }^{15}$ Few Native Americans saw the ICRA as a protection of their individual rights against tribal violations. Instead, most Indians saw it as a federal intrusion into tribal affairs. ${ }^{16}$

Congress stated that this "Indian Bill of Rights" was needed to protect individual Indians against abuses by the tribes ${ }^{17}$ because Indians had no federal or state constitutional rights vis-à-vis the tribes. ${ }^{18}$ In order to justify the imposition of these federally created rights, the ICRA restated the idea of limited sovereignty: Indian sovereignty exists alongside the plenary right of Congress to regulate and modify the status of tribes. ${ }^{19}$ In this respect, tribal rights resemble the rights of the states. ${ }^{20}$

In the years surrounding the passage of the ICRA, the Supreme Court struggled with the limits of tribal sovereignty. One attempt to define the scope of this sovereignty is the preemptive test, which was set out in Williams $v$. Lee. ${ }^{21}$ In that case, the Supreme Court held a state law inapplicable if it in-

14. Pub. L. No. 90-284, 82 Stat. 77 (codified at 25 U.S.C. $\$ \$ 1301-41$ (1988)). The ICRA marked the entrance into the modern era of federal Indian law. Although a detailed history of federal Indian policy is beyond the scope of this Note, the position of the United States government generally has moved from an emphasis on integration to a focus on increased tribal sovereignty.

The United States advanced the integration position during two eras. The first era, which was marked by efforts at assimilation, lasted from the beginning of colonization until the end of World War II. For a discussion of this period in Native American history, see VINE DELORIA, JR. \& CLIFFORD M. LYTLE, AMERICAN INDIANS, AMERICAN JUSTICE 1-15 (1983). In the second era, the government designed a program of termination to eliminate all the special restrictions and privileges that went with the "Indian" label. H.R. Con. Res. 108, 83d Cong., 1st Sess. (1953).

Finally, the 1960's ushered in the movement for Indian sovereignty, culminating in the passage of the ICRA. This Act advanced the tribal sovereignty position in federal Indian policy. The ICRA recognized a limited tribal sovereignty requiring the tribal governments to act within quasi-constitutional bounds.

15. 25 U.S.C. $\S 1302$ (1988).

16. WilliaM C. CANBY, JR., AMERICAN INDIAN LAW 246 (2d ed. 1988).

17. S. REP. NO. 841 , supra note 7 , at 5-6.

18. It is normally not possible to invoke the Bill of Rights or Fourteenth Amendment against a tribe. Talton v. Mayes, 163 U.S. 376, 382-83 (1896).

19. For a discussion of the plenary powers of Congress, see supra note 2.

20. For example, the Court in National Farmers Union Insurance Cos. y. Crow Tribe of Indians, 471 U.S. 845, 851-52 (1985), cited authority involving state courts and drew a direct analogy between tribes and states.

21. 358 U.S. 217 (1959). 
fringed on a tribe's right to make its own laws and to be governed by them. ${ }^{22}$ The Williams Court favored protecting tribal autonomy, but the 1978 Supreme Court limited tribal autonomy by holding in Oliphant $v$. Suquamish Indian Tribe $^{23}$ that Indian tribes did not have criminal authority over non-Indians on the reservation except as permitted by Congress. ${ }^{24}$ Three months later, the Court switched sides again in Santa Clara Pueblo v. Martinez. ${ }^{25}$ By denying federal protection against gender discrimination to an Indian woman, ${ }^{26}$ the Court refused to encroach upon the sovereignty of a tribe.

\section{Santa ClaRa: Tribal SOVEREIGNTY TAKes THE DAY}

Santa Clara Pueblo v. Martinez addressed the conflict between Indian autonomy and gender discrimination. Julia Martinez and her daughter challenged a Santa Clara Pueblo membership ordinance that disqualified Mrs. Martinez's children because Mrs. Martinez had married outside of the tribe. ${ }^{27}$ The membership ordinance placed no such restriction on men. ${ }^{28}$ Martinez argued that the membership rule discriminated against her solely on the basis of sex, and therefore, the Act violated Title I of the ICRA. Title I states that "[n]o Indian tribe in exercising powers of self-government shall . . . deny to any person within its jurisdiction the equal protection of its laws . . .."29

The Supreme Court considered three issues in Santa Clara: (1) whether tribes had waived their immunity to suit in federal court under the ICRA; (2) which court was the proper forum in which to challenge violations of the ICRA; and (3) whether habeas corpus relief was the only remedy available under the ICRA.

22. Id. at 220-23.

23. 435 U.S. 191 (1978).

24. Id. at 210 .

25. 436 U.S. 49 (1978).

26. Id. at 72-73.

27. Mrs. Martinez brought this case in federal district court. Martinez v. Santa Clara Pueblo, 402 F. Supp. 5 (D.N.M. 1975). Native Americans can always bring their claims in tribal court, but this may be futile in some instances. For example, the Santa Clara tribe has a single governing body, the Council, which possesses both legislative and appellate judicial powers. Original jurisdiction is vested in the Governor. However, the Governor is appointed by the Council. SANTA CLARA CoNST. art. IV, \$§ 1-2, summarized in Martinez, 402 F. Supp. at 13. Therefore, Mrs. Martinez would have had to bring her grievances to the same ruling body that adopted the discriminatory membership laws.

28. The sections of the ordinance read in pertinent part:

2. [Clhildren born of marriages between male memters of the Santa Clara Pueblo and nonmembers shall be members of the Santa Clara Pueblo.

3. [C]hildren born of marriages between female members of the Santa Clara Pueblo and nonmembers shall not be members of the Santa Clara Pueblo.

Santa Clara, 436 U.S. at 52 n.2.

29. 25 U.S.C. $\$ 1302(8)(1988)$. 


\section{A. Sovereign Immunity}

Although three months earlier the Court had limited the territorial sovereign powers of tribal governments, ${ }^{30}$ the Court now chose to expand sovereignty by holding that "Indian tribes have long been recognized as possessing the common-law immunity from suit traditionally enjoyed by sovereign powers."31 The Court went on to state that a waiver of sovereign immunity must therefore be expressed unequivocally and cannot simply be implied. ${ }^{32}$

\section{B. Tribal Forum}

According to the Court, the ICRA recognized that tribes are in the best position to understand their own culture ${ }^{33}$ and therefore modified the Bill of Rights to accommodate the "unique political, cultural, and economic needs of tribal governments." 34 Under this exclusive forum doctrine, federal courts should defer to the tribal courts' adjudication of civil matters..$^{35}$

However, a later decision read Santa Clara's exclusive forum doctrine narrowly. The Tenth Circuit in Dry Creek Lodge, Inc. v. Arapahoe \& Shoshone Tribes ruled that if the tribal court fails to provide an adequate forum in which to address civil grievances, a federal court may assume jurisdiction. ${ }^{36}$ Under this reasoning, Mrs. Martinez would have been allowed access to federal court, because her efforts in the tribal system had been prejudiced from the start. ${ }^{37}$

30. See Oliphant v. Suquamish Indian Tribe, 435 U.S. 191 (1978) (Indian tribes lack authority to punish non-Indian who commits crime on reservation). The distinction between Oliphant and Santa Clara is that while Oliphant dealt with territorial sovereignty over non-Indians, Santa Clara did not question tribal sovereignty over Indians.

31. Santa Clara, 436 U.S. at 58.

32. Id.

33. Tribes argue that the right to determine their own membership laws, however discriminatory, is necessary for cultural survival. In response, Catharine MacKinnon asks: "Why is it seen as a matter of cultural survival when men guarantee exclusive access to Indian women as a requirement of tribal membership, but when an Indian woman attempts to claim that her family is an Indian family, to choose who to make a family with, it's called a threat to cultural survival?" CATHARINE A. MACKINNON, Whose Culture? A Case Note on Martinez v. Santa Clara Pueblo (1983), in FEMINISM UNMODIFIED 63, 67 (1987).

Moreover, the discriminatory treatment of women, which tribes sought to enforce by claiming it as part of their culture, stands in sharp contrast to the equality women had enjoyed in tribal history. See infra notes 68-75 and accompanying text; see also Resnik, supra note 9, at 705-12.

34. Santa Clara, 436 U.S. at $62-63$ (footnote omitted).

35. See generally id. at 61-71 (discussing why tribal courts are "appropriate forums" for adjusting such civil disputes).

36. 623 F.2d 682, 685 (10th Cir. 1980), cert. denied, 449 U.S. 1118 (1981). The court reasoned that "unwarranted intrusions" on personal liberty would be fundamentally unfair and inconsistent with the underlying intent of the ICRA. Therefore, denial of an adequate forum would act as an implicit waiver of the tribal court's immunity. Id. at 684-85.

37. See supra note 27 . 


\section{Habeas Corpus}

In Santa Clara, the Supreme Court reasoned that Congress retained plenary power over the Indian tribes but had, in passing the ICRA, provided only for habeas corpus relief. ${ }^{38}$ Since Congress did not specifically include the remedy of judicial review for civil actions, the Court reasoned, federal courts have no right to interfere with the tribes' internal and social relationships. ${ }^{39}$ However, in summarizing congressional intent, the Court declared: "[A] central purpose of the ICRA and in particular of Title I was to 'secur[e] for the American Indian the broad constitutional rights afforded to other Americans,' and thereby to 'protect individual Indians from arbitrary and unjust actions of tribal governments." "40 Upon examining congressional intent, it is hard to imagine that Congress wanted to protect individuals but was unwilling to provide a judicial remedy ensuring such protection. Nevertheless, according to the Court, the legislative history suggests that "Congress' failure to provide remedies other than habeas corpus was a deliberate one," and the Court was unpersuaded that fulfillment of the purposes of the ICRA requires intrusion into tribal sovereignty. ${ }^{41}$

Santa Clara left Native American women a right without a remedy. The next part of this Note argues that Congress should resolve this quandary for Native American women. Then, Part IV proposes a remedy that establishes guidelines for amending legislation.

\section{The Case for Expanding the Indian Civil Rights ACT}

After the Santa Clara decision, Native American women could not rely on the protection of state and federal courts. Women denied tribal membership lost essential benefits of membership, including federal payments, education, and health services. ${ }^{42}$

Congress could have remedied this problem immediately, as it had done when it passed the Major Crimes Act, ${ }^{43}$ which reduced tribal sovereignty in response to the Crow Dog decision. ${ }^{44}$ Indeed, the Supreme Court noted in Santa Clara that if the tribal courts prove inadequate to apply and enforce the

38. Santa Clara, 436 U.S. at 61 . "The privilege of the writ of habeas corpus shall be available to any person, in a court of the United States, to test the legality of his detention by order of an Indian tribe." 25 U.S.C. § 1303 (1988).

39. Santa Clara, 436 U.S. at 55-58, 69-72.

40. Id. at 61 (quoting S. REP. No. 841, supra note 7, at 5-6).

41. Id. at 61 .

42. Deprivation of material benefits, especially medical care, was a central hardship factor driving the Santa Clara case. Julia Martinez's daughter was denied medical treatment because she had no tribal recognition and later died from strokes relating to her terminal illness. Brief for Respondent at 4 , Santa Clara (No. 76-682).

43. Act of June 25,1948 , ch. 645,62 Stat. 758 (codified at 18 U.S.C. $\S 1153$ (1988)).

44. Ex parte Crow Dog, 109 U.S. 556 (1883). This case held that an Indian tribe had jurisdiction over a case where one Indian murdered another on the reservation. Id. at 570-72. 
ICRA, Congress could similarly exercise its plenary power and grant federal courts jurisdiction over civil rights violations. ${ }^{45}$

\section{A. Findings of the U.S. Civil Rights Commission}

The U.S. Civil Rights Commission recently held a series of hearings to determine whether the statutory duty to enforce the ICRA is being fulfilled. ${ }^{46}$ Since Santa Clara, there have been 280 complaints of ICRA violations filed against Indian tribes. ${ }^{47}$ Most of the tribes' self-governing powers center on the internal affairs of the community. ${ }^{48}$ As a result, tribal membership and participation of women are common targets of tribal ICRA violations. Therefore, Native American women need specific gender protection to guarantee them the rights enjoyed by other women in the United States. ${ }^{49}$

\section{B. Weighing Individual and Group Rights}

In its recent dealings with cultural minorities, ${ }^{50}$ the government has sought to strike a balance between cultural and individual rights. ${ }^{51}$ Although groups do not receive explicit rights, courts have frequently awarded them constitutional protection. Relying on the privacy, speech, and association norms of the First and Fourteenth Amendments, the Court has ruled that groups have the right to refuse to divulge membership lists. ${ }^{52}$ Religious groups have also been granted rights under the Free Exercise Clause of the First Amendment to obtain

45. Santa Clara, 436 U.S. at 56. At least one commentator has argued that the decision not to take legislative action in the aftermath of Santa Clara illustrates the federal government's values: in United States culture, it is acceptable to subordinate women. Resnik, supra note 9, at 755.

46. See generally Enforcement of the Indian Civil Rights Act: Hearings Before the United States Commission on Civil Rights (July 3, 1986-Oct. 4, 1990) (establishing commission to determine effectiveness of ICRA by holding open hearings throughout United States) [hereinafter Hearings].

47. 134 CONG. REC. S11,652 (daily ed. Aug. 11, 1988) (discussing amendment to the ICRA proposed by Senator Hatch referring to testimony by Department of Justice before United States Civil Rights Commission).

48. See, e.g., Fisher v. District Court of Mont., 424 U.S. 382, 389-90 (1976) (Indian tribe has power to exercise jurisdiction in adoption proceeding involving members of tribe).

49. See, e.g., Reed v. Reed, 404 U.S. 71 (1971) (state's arbitrary preference for males over females, without regard to qualifications, violates Fourteenth Amendment's Equal Protection Clause).

50. The term "cultural minorities" refers to the many ethnic, religious, and racial groups that are present in the United States. More than 100 ethnic groups and 170 American Indian groups have been identified. HARVARD ENCYCLOPEDIA OF AMERICAN ETHNIC GROUPS, at vi (1980).

51. In the area of Native American law, this has often led to jurisdictional confusion among the courts. The courts have fluctuated between awarding jurisdiction to the states and awarding it to the tribes based upon an unclear weighing of interests. See, e.g., New Mexico v. Mescalero Apache Tribe, 462 U.S. 324, 334 (1983) (state jurisdiction preempted when it interferes or is incompatible with tribal interests, unless state interests are sufficient to justify state authority).

52. See NAACP v. Alabama ex rel. Patterson, 357 U.S. 449, 462-63, 466 (1958) (order requiring NAACP to produce membership list restricts members' freedom of association rights). 
exemptions from regulations that unnecessarily burden their religious practices. $^{53}$

However, the government has sometimes found it necessary to infringe upon a group's culture in order to preserve preemptory individual rights. ${ }^{54}$ Through antidiscrimination laws, the United States has attempted to change its own culture, which has traditionally discriminated against minorities. ${ }^{55}$ The government has imposed this change upon a culture that would prefer to maintain the status quo, despite its oppression of minorities. ${ }^{56}$

For example, the post-Civil War Reconstruction imposed a foreign culture upon the South. ${ }^{57}$ One of the focal points of Southern culture had been the belief that African Americans did not deserve the same rights as white males. Judith Resnik observes that "[m]any of us [applauded] the imposition of federal norms on communities that said that their culture, their custom, was to treat whites differently than blacks." ${ }^{\text {}} 8$ This imposition on Southern culture represented a belief that groups, in this case African Americans, have a right to be free from discrimination or stigmatization by the state. ${ }^{59}$

The women's suffrage movement is another example of displacing cultural norms in an effort to guarantee an important civil right. ${ }^{60}$ Women won the right to vote, even though the majority within the traditional Western culture would have preferred to continue the historic inequality. ${ }^{61}$ Indeed, the United

53. See, e.g., Wisconsin v. Yoder, 406 U.S. 205, $215-19$ (1972) (compulsory education law endangers free exercise rights of Amish children); Teterud v. Burns, 522 F.2d 357, 362-63 (8th Cir. 1975) (prison regulations requiring short hair violate rights of American Indian inmates to freely practice their religion). Similarly, during the Prohibition Era, certain cultural groups, namely Catholic and Jewish people, were allowed to use wine in religious ceremonies, and until recently, Native Americans were permitted to use peyote in traditional religious ceremonies. But see Employment Div. v. Smith, 110 S. Ct. 1595 (1990) (Free Exercise Clause does not prevent state from prohibiting sacramental peyote use).

54. These rights include: freedom of religion, speech, and association; equal representation; fair trial; and protection of property. "Individuals should be equally protected in their access to these rights without distinction as to race, color, sex, religion, or national origin." Sharon O'Brien, Cultural Rights in the United States: A Conflict of Values, 5 LAW \& INEQ. J. 267, 283 (1987).

55. See, e.g., JAMES OLSON, THE ETHNIC DIMENSION IN AMERICAN HISTORY 44 (1979) (providing history of enslavement of African Americans); Ronald Takaki, Reflections on Racial Patterns in America: An Historical Perspective, in 1 ETHNICITY AND PUBLIC POLICY 1, 5 (Van Horne ed., 1982) (discussing events surrounding 1882 Chinese Exclusion Act).

56. See infra notes 62-63 and accompanying text.

57. Cf. Bruce Ackerman, The Storrs Lectures: Discovering the Constitution, 93 YALE L.J. 1013, 1063 69 (1984) (referring to fact that Thirteenth Amendment was enacted by excluding participation of representatives of defeated Confederate States). Similarly, the civil rights movement imposed values on the whole of the United States.

58. Resnik, supra note 9, at 747 .

59. The Thirteenth Amendment, in addition to abolishing slavery, also gave Congress the power to abolish "all badges and incidents of slavery in the United States." The Civil Rights Cases, 109 U.S. 3, 20 (1883).

60. Susan B. Anthony and 13 other women were arrested in 1872 when they first attempted to cast their votes. A criminal charge was entered against them for "having voted without the lawful right to vote," a charge which carried a possible three-year jail term. BARBARA A. BABCOCK ET AL., SEX DISCRIMINATION AND THE LAW 8-9 (1975).

61. Six states-Georgia, Louisiana, Mississippi, North Carolina, South Carolina, and Virginia-have never ratified the Nineteenth Amendment to the Constitution which grants women the right to vote. ALAN P. GRIMES, DEMOCRACY AND THE AMENDMENTS TO THE CONSTITUTION 96 (1978). 
States has gradually awarded more protection to women by striking down discriminatory work practices ${ }^{62}$ and pay scales. ${ }^{63}$ Likewise, courts have begun to demand equality of treatment by other groups which have traditionally discriminated against women. ${ }^{64}$

\section{The Victimization of Native American Women}

Native American people, and in particular Native American women, have suffered a longer history of discrimination in the United States than any minority group. Much of this discrimination arose out of the government's policies of assimilation, ${ }^{65}$ termination, ${ }^{66}$ and genocide. ${ }^{67}$

Although historically nonsexist, Native American cultures have been altered by contact with European cultures. Historically, in many North American Indian tribes, women enjoyed equal rights with men and in some cases were even considered superior to men. Descriptions from colonial times stated that "[w]omen received the honor and respect that no other people gave their women." 68

62. See Rosenfeld v. Southern Pac. Co., 444 F.2d 1219 (9th Cir. 1971) (company's policy of excluding women from certain positions and state laws restricting women's work hours violated Title VII of Civil Rights Act of 1964).

63. The Equal Pay Act was enacted in 1963. 29 U.S.C. $\$ 206$ (d) (1988). The Act prohibits an employer from discriminating "between employees on the basis of sex." See also Shultz v. Wheaton Glass Co., 421 F.2d 259 (3d Cir. 1970), cert. denied, 398 U.S. 905 (1970) (equal pay for "equal" work mandated under Act does not require jobs to be identical, but only substantially equal).

64. Resnik, supra note 9, at $747 \mathrm{n} .365$ (discussing decisions forcing traditionally men-only clubs to admit women). Even Ronald Garet, who argues for the increased importance of group rights, recognizes that "[i]t is by no means certain that protection of Santa Clara communality requires enforcement of the discriminatory membership rule." Ronald R. Garet, Communality and Existence: The Rights of Groups, 56 S. CAL. L. REV. 1001,1065 n.157 (1983).

65. See FELIX COHEN, HANDBOOK OF FEDERAL INDIAN LAW 661 (1982) (national policy "sought to assimilate the Indians and end their distinctive status by persuasion and strong inducements, sometimes backed by indirect coercion").

66. "Termination" refers to the policies advanced by the United States government in which it attempted to terminate the special relationship between the federal government and the Native American tribes. Some aspects of the termination program included transferring tribal land into private ownership, awarding states jurisdiction over tribal territory, and eliminating federal services to Native Americans. CANBY, supra note 16 , at 52-54. See generally COHEN, supra note 65 , at 152-80 (discussing termination periods advanced by United States government).

67. An investigation into the United States Indian Health Service estimated that the Service had sterilized more than $25 \%$ of all American Indian women and had usually talked the women into the operation in a "very authoritarian, or coercive manner." Who Are These Women?, in Hearings, supra note 46, at 23-25 (Mar. 19-20, 1979) (exhibit submitted by Women of All Red Nations).

For a documented account of the systematic plunder and elimination of the American Indians, see DEE BROWN, BURY MY HEART AT WOUNDED KNEE: AN INDIAN HISTORY OF THE AMERICAN WEST (1970). President Jackson, known as Sharp Knife by Indians, and his soldiers slaughtered thousands of southern Indians during his frontier career. Id. at 5.

68. RICHARD P. BOWLES ET. AL., THE INDIAN: ASSIMILATION, INTEGRATION OR SEPARATION? 176-77 (1972) (speaking specifically about characteristics of the Iroquois Indians in New York); see also I AM THE FIRE OF TIME: THE VOICES OF NATIVE AMERICAN WOMEN, at xvii (Jane B. Katz ed., 1977) [hereinafter FIRE OF TIME] ("Most Indian societies acknowledged woman's vital role in the creative process. In tribal ceremonies and lore she was portrayed as the giver of life. Pueblo peoples prayed for 'female rain.' Some tribes believed that woman had mystical power over the life cycle."); JOHN U. TERRELL \& DONNA M. TERRELL, INDIAN WOMEN OF THE WESTERN MORNING: THEIR LIFE IN EARLY AMERICA 27 (1974) ("The assertion that an Indian woman was an abject drudge of her tribe's men, both before and after marriage, 
Indeed, some tribes were completely matrilineal, matrifocal, and matrilocal; ${ }^{69}$ and in many Indian cultures, personal property belonged to the women, not to their husbands. ${ }^{70}$ Although a division of labor existed between the sexes, that division was considered complementary and not a symbol of subordinate status as in Western culture. ${ }^{71}$

In the political arena as well, women were considered equal to men. For instance, in the Iroquois tribe, women played the major role in the selection of the tribe's ruling body:

When a chief died, the women of his tribe and clan held a meeting at which a candidate for the vacant place was decided upon. A woman delegate carried the news to the chiefs of the clans which belonged to the 'side' of the deceased chief's clan. They had the power to veto the selection, in which case another women's meeting was called and another candidate selected ... . ${ }^{72}$

The Europeans, however, found this to be counterintuitive to their vision of the "proper" status of women and sought to teach the Indians "suitable" sex roles. ${ }^{73}$ They believed women should fit the role of a helpless helpmate. One California Indian agent reported that she "hoped to correct" the Indian woman's practice of retaining her maiden name and passing it on to her daughters. ${ }^{74}$ The United States government attempted to assimilate Indians into the dominant society by destroying aspects of the Indian culture. One of the casualties of Native American culture was equality for Indian women. The United States government chose only Indian men as leaders because in their society only men could be rulemakers. ${ }^{75}$

Now the United States has stepped back from the discriminatory culture it helped to create, leaving Indian women to fend for themselves. Although the

is completely without foundation.").

69. See ROBERT H. LOWIE, INDIANS OF THE PLAINS 96-97 (1954) (referring to the tribes of the Crow, Hidatsa, Mandan, and Pawnee); TERRELL \& TERRELL, supra note 68, at 28-29 (matrilineal tribes included Iroquois, Siouan, Mohegan, Delaware, Powhatan, Creek, Choctaw, Chickasaw, Seminole, Caddoan linguistic family, Pawnee, Hidatsa, Mandan, Oto, Missouri, Crow, Navajo, Hopi, Laguna, Acoma, and Zuni).

70. TERRELl \& TERRELl, supra note 68, at 29; Linda J. Lacey, The White Man's Law and the American Indian Family in the Assimilation Era, 40 ARK. L. REV. 327, 344 (1986).

71. TERRELL \& TERRELL, supra note 68 , at 4 ("The concept that woman was made from man is not found in Indian religion. Indians accept and adhere to the doctrine that the female of their kind was created simultaneously with the male. For apparent reasons, each was endowed with peculiar qualities and sensibilities, neither was accorded supremacy, and each was made dependent upon the other for existence.")

72. Judith K. Brown, Iroquois Women: An Ethnohistoric Note, in TOWARD AN ANTHROPOLOGY OF WOMEN 239 (Rayna R. Reiter ed., 1975) (citing Alexander A. Goldenweiser, On Iroquois Work: 1912, in SUMMARY REPORT OF THE GEOLOGICAL SURVEY OF CANADA 468 (1912)); see also Sarah W. Hopkins, The Women Know as Much as the Men, in FIRE OF TME, supra note 68, at 43 ("The women know as much as the men do, and their advice is often asked. We have a republic as well as you. The council-tent is our Congress, and anybody can speak who has anything to say, women and all.").

73. Lacey, supra note 70 , at 358 .

74. Id. at 368 .

75. Rayna Green, Native American Women, 6 SIGNS 248, 253 (1980). 
ICRA is designed to protect individual rights from encroachments by the tribe, Native American women are powerless to enforce such rights after the Santa Clara decision. Women may be discriminatorily denied tribal membership along with all of the benefits that accompany membership. Often rejected by and culturally different from white society, many American Indian women may not return to their former society, which includes most of their families.

\section{A PROPOSAL FOR EXPANDING THE INDIAN CIVIL RIGHTS ACT}

The ICRA was passed to protect individual Indians and requires tribes to enforce its provisions. ${ }^{76}$ Current membership laws reveal that many Native American women are denied rights afforded to Native American men. For example, the Cachil Dehe Band of Winton Indians discriminates against women. The tribal constitution states:

[1]f a female member marries a non-Indian, she will automatically lose her membership and will be required to leave the Community within ninety days after written notice has been served upon her by the Business Committee; Provided, That this provision shall not apply in the case of any marriages consummated prior to the approval of this Constitution and By-Laws. ${ }^{77}$

Although tribes deprive women of their civil rights, the doctrine established in Santa Clara declines to hold the tribes accountable in federal court for their discriminatory actions. ${ }^{78}$ Consequently, a Native American woman discriminated against by a tribe lacks a forum in which to bring her complaint. ${ }^{79}$ The amendment proposed in this Note remedies the no-forum situation and allows Native American women to rely upon the guarantees embodied in the ICRA. A similar amendment to the ICRA was proposed by Senator Orrin Hatch of Utah in 1988. However, as discussed below, the Hatch Amendment allows too much federal intrusion upon tribal sovereignty.

76. See Hearings, supra note 46, at 85 (excerpt from meeting of United States Commission on Civil Rights, Feb. 11, 1986).

77. CACHIL DEHE BAND OF WINTON INDIANS OF the COLUSA INDIAN COMMUNITY/CAL. Const. art. II, §4. The constitution of the Kiahlagee Tribe also discriminates by allowing all adult children of male members, but not of female members, to become members of the tribe by acceptance of members present at a tribal meeting. KIAHLAGEE TRIBAL TOWN/OKLA. CONST. art. III, $\$ 5$, reprinted in Elmer Rusco, Civil Liberties Guarantees Under Tribal Law: A Survey of Civil Rights Provisions in Tribal Constitutions, 14 AM. INDIAN L. REV. 269, 284 (1989).

78. See supra text accompanying notes $27-34$.

79. See Dehose v. Johnson (White Mountain Apache Tribal Court, Whiteriver, Ariz., Feb. 22, 1989) (dismissal of woman's suit because of sovereign immunity doctrine) reprinted in Hearings, supra note 46, at 233 (Sept. 29, 1989). 


\section{A. United States Legislative Approach}

On August 8, 1988, Senator Orrin Hatch introduced a bill to amend the ICRA. ${ }^{80}$ If the amendment had passed, it would have granted federal courts jurisdiction over claims that tribal courts had deprived individuals of their civil rights. ${ }^{81}$ Jurisdiction would have been based on the plenary power of Congress over Indian matters and would only have been allowed after the exhaustion of tribal court remedies. ${ }^{82}$

If Congress had approved the amendment, Indian tribes would likely have viewed it as an intrusion on their sovereign powers. ${ }^{83}$ Although such an intrusion is within congressional powers, as demonstrated by the Major Crimes $\mathrm{Act}^{84}$ and the ICRA, ${ }^{85}$ Hatch's proposal would have opened too many avenues for federal intervention into tribal sovereignty.

Hatch's bill demonstrates a misunderstanding of the problems facing Indian litigants when dealing with tribal governments. In his statement to the Senate, Hatch reported that "tribal members enjoy the protection of their rights under both the United States Constitution and the ICRA .... [I]t appears that nonIndians are not granted the same privilege of dual citizenship in the Tribal Court." ${ }^{\text {86 }}$ This overlooks the problem, illustrated by Santa Clara, that tribal members, instead of being afforded dual privileges, are left with no privileges when dealing with the tribal government. ${ }^{37}$

Hatch proposed granting federal jurisdiction in two situations. First, federal court jurisdiction should be conferred automatically in civil actions alleging a denial of rights after the exhaustion of tribal remedies. ${ }^{88}$ Second, in special circumstances, the Attorney General should be able to obtain federal jurisdiction for a lawsuit by the United States without the exhaustion of tribal remedies. ${ }^{89}$

Hatch used Santa Clara to win support for his bill by demonstrating how individual civil rights were being violated. ${ }^{90}$ However, Hatch's bill was too expansive and would have done little to preserve tribal sovereignty. The

80. 134 CONG. REC. S11,656 (daily ed. Aug. 11, 1988) (statement of Senator Hatch). The Hatch Amendment to the ICRA was never brought to the Senate floor for a vote.

81. Id. at $\$ 11,654$.

82. Id. at $\$ 11,653, \$ 11,656$.

83. Hearings, supra note 46 , at 9 (Sept. 29, 1988). The testimony of Tom Tso, Chief Justice of the Navajo Nation reflects this distrust. Tso stated that he wondered if investigation into enforcement of ICRA had been undertaken "in order to help Indian nations or simply Ito] find justification for Senator Hatch's or other persons' proposals?" Id.

84. See supra note $\mathbf{4 3}$ and accompanying text.

85. See supra text accompanying notes 14-20.

86. 134 CONG. REC. S11,654 (daily ed. Aug. 11, 1991) (statement of Senator Hatch) (quoting Little Horn State Bank v. Crow Tribal Court, 690 F. Supp. 919, 923 (D. Mont. 1988), vacated, 708 F. Supp. 1561 (D. Mont. 1989)).

87. See supra note 27 and accompanying text.

88. 134 CONG. REC. $\$ 11,655$ (daily ed. Aug. 11, 1988).

89. Id. at $S 11,655-56$.

90. Id. at $\$ 11,654$ ("Because of the enforcement problems that have occurred since the Martinez case, time has now come to follow the Supreme Court's dictum and legislate a Federal court remedy."). 
amendment did not strike a balance between the needs of individual Indians and tribal authority. ${ }^{91} \mathrm{By}$ limiting the amendment, the proposal outlined in this Note seeks to preserve as much tribal sovereignty as possible, thereby striking a better balance between individual and tribal interests.

Congress has the plenary power over Indian tribes to pass an amendment to the ICRA. Passing a bill to prevent discrimination against women would be an extension of a much larger intrusion on Native American sovereignty already imposed by the ICRA. However, the benefits of providing Native American women with a voice in their own community weighs heavily in favor of such protection. Support for the imposition of gender protection can be found in the international community, which recognizes the pervasive problem of gender discrimination.

\section{B. A Forum for Native American Women}

In 1967, the United Nations adopted the Declaration on the Elimination of Discrimination Against Women, which expressed a concern that women around the world were being denied equal rights. ${ }^{92}$ It also recommended guidelines for adoption by member states to address gender discrimination..$^{93}$

The amendment proposed in this Note follows international standards of equality and adds a new section to the ICRA to prevent discrimination against Native American women, especially in the membership arena. Because many tangible and intangible benefits accompany tribal membership, ${ }^{94}$ special steps must be taken to ensure these benefits equally for men and women. The propos-

91. Hatch asserted that "the bill that I am proposing today strikes a legitimate balance between the interests of the tribal governments in exercising their powers of self-government and the rights which Congress extended to individuals through the 1968 Indian Civil Rights Act." Id. at S11,656.

92. Declaration on Elimination of Discrimination Against Women, art. 5, 1967 U.N.Y.B. 518, U.N. Doc. A/6716/1967. The United Nations declared that "[w]omen shall have the same rights as men to acquire, change or retain their nationality" and that "[m]arriage to an alien shall not automatically affect the nationality of the wife either by rendering her stateless or by forcing on her the nationality of her husband." Declaration of Human Rights, [1948] 3 Y.B. Int'l L. Comm'n 15, U.N. Doc. A/811/1948.

93. Native American women need protection against gender discrimination within the Indian community. The international community provides precedents for such protection in guidelines set forth by the United Nations which is both multinational and multiethnic in its scope. For instance, the United Nations Human Rights Committee criticized a gender-discriminatory Canadian Indian law. See Lovelace v. Canada, 36 U.N. GAOR Supp. No. 40, U.N. Doc. A/3640 (1981); International Covenant on Civil and Political Rights, 21 U.N. GAOR Supp. No. 16, § 15, U.N. Doc. A/6316 (1966), reprinted in Human Rights: A Compilation of International Instruments 8, U.N. Doc. ST/HR/1/Rev.2 (1983).

Canada, responding to this criticism from the international community, removed the gender-discriminating section of the Indian Act. Bill C-31, An Act to Amend the Indian Act, R.S.C., ch. 32 (1st Supp. 1985) (Can.). Although Bill C-31 does not eliminate discrimination perfectly, many Indian groups, including the Native Women's Association of Canada, view it as a starting point to the eventual elimination of all discrimination in the Canadian Indian Act. NATIVE WOMEN's ASSOCLATION OF CANADA, POSITION PAPER ON THE INDIAN ACT 2-4 (1989).

It is important to note that international law is governed by consent. The Native American tribes are not represented independently at the United Nations, and one could argue, therefore, that the tribes did not consent to any proposals passed by the United Nations.

94. See JAMIESON, supra note 11, at 67-74; Paul, supra note 12. 
al prohibits tribal laws that discriminate on the basis of gender and provides a two-year implementation period to give the tribes time to bring their laws into compliance. $^{95}$

By creating a special amendment to deal exclusively with the issue of gender discrimination, this proposal tries to avoid the problem of the Hatch amendment by minimizing encroachment on tribal courts' sovereignty. The amendment focuses on membership for two reasons. First, monetary benefits flow from membership. Second, these benefits are usually funded with federal money, and, therefore, the disparate treatment of Native American men and women constitutes discriminatory state action.

The remaining sections of this Note present and explain the language of the proposed amendment. The language chosen is designed to expand the ICRA narrowly, providing for specific gender protection while respecting a limited tribal sovereignty.

\section{Language of the Proposed Amendment}

The Amendment should read:

$\S 1$ Equal Rights

No Indian tribe, or tribal authority receiving federal moneys, in exercising powers of self-government shall:

(1) make or enforce any law that abridges the right to acquire, change, retain, or pass down tribal membership on the basis of sex;

(2) violate the rights of women to participate in the political life of the tribe on equal terms with men, including:

(a) the right to vote in all elections and to be eligible for election to all publicly elected bodies;

(b) the right to vote in all public referenda; and

(c) the right to hold public office and to exercise all public functions; or

(3) deny on the basis of sex the right to acquire, administer, enjoy, inherit, or bequeath property.

\$ 2 Application and Remedy

(1) The Amendment to the Indian Civil Rights Act shall not have effect until two years after it is adopted by Congress.

(2) A violation of $\S 1$ of this Amendment shall effect waiver of the tribe's sovereign immunity from suit under $\$ 2(3)$ of this Amendment.

(3) Any aggrieved Native American, following the exhaustion of tribal remedies or a showing that such exhaustion would be futile, may sue in federal district court for declaratory, injunctive, or other equitable relief against an Indian tribe, tribal organization, or official thereof, alleging a failure to comply with rights secured by this Amendment.

95. For a discussion of the limited retroactivity of the legislation, see infra note 101. 


\section{Explanation of the Proposed Amendment}

The proposed amendment allows Native American women the same equal protection within their community that all United States citizens enjoy. ${ }^{96}$ The language of the amendment focuses only on tribal membership laws, because most benefits flow from membership status. At present, the benefits flow from federal moneys that are allocated to the tribes, creating the appearance that the discrimination is federally funded. The proposed limiting language retains protection for tribal interests found in the ICRA, while guaranteeing women the constitutional benefits originally envisioned under the ICRA.

\section{Federal Funding ${ }^{97}$}

The proposed amendment is limited to tribes or tribal authorities "receiving federal moneys." Native American women who lose their status as tribal members suffer economic hardship because they lose access to the government funds and programs that are allocated to the Indian tribes. For example, any "member of an Indian tribe" is a beneficiary of the Indian Self Determination and Education Assistance Act. ${ }^{98}$ Tribes that discriminate against women, thereby denying them the economic benefits under this Act, violate 20 U.S.C. $\S 1681$. Section 1681 states: "No person in the United States shall, on the basis of sex, be excluded from participation in, be denied the benefits of, or be subjected to discrimination under any education program or activity receiving Federal financial assistance...."99

\section{Section 1: Equality}

Section 1(1) of the amendment addresses the concerns of three groups: (1) Native American women subject to discriminatory membership laws, (2) Native American women who are denied tribal membership due to genderbiased laws, and (3) children of groups (1) and (2) who are denied member-

96. The proposed amendment will also protect the interests of men who have suffered discrimination by a tribe. For example, the Crow and Quapaw tribes allow women to vote in tribal elections when they are 18 years old; men, however, cannot vote until they are 21. CROW TRIBAL COUNCIL CONST. art. III, reprinted in Rusco, supra note 77, at 285; Resolution Delegating Authority to the Quapaw Tribal Business Committee (Aug. 19, 1936), reprinted in id.

97. The federal funding, or benefits, may also be thought of as reparations. Most of the payments to the tribes are based on treaty provisions.

98. 25 U.S.C. § 450(b) (1988).

99. 20 U.S.C. $\$ 1681$ (a) (1989). Moreover, denying federally funded health benefits to Native American women would also violate 42 U.S.C. \$ 3123 , which states: "No person in the United States shall, on the ground of sex, be excluded from participation in, be denied the benefits of, or be subjected to discrimination under any program or activity receiving Federal financial assistance under [this chapter]." 42 U.S.C. § 3123 (1989). 
ship. ${ }^{100}$ This section will prohibit the gender discrimination generally imposed on Native American women who marry outside the tribe. The words "acquire" and "change" allow women who have married nonmembers and lost their status as members of the tribe to seek the reinstatement of their tribal membership. ${ }^{101}$ The word "retain" ensures that no additional women will lose their membership for marrying a nonmember. Finally, the "pass down" language prevents children from being excluded as a result of their mothers' marriages to non-Native Americans, and it allows children who already have been excluded to become members.

The "pass down" provision addresses an important issue, because adverse psychological effects accompany the monetary benefits lost by nonrecognized children:

"If Indian women who have lost their rights cannot pass their band membership to their children, it is likely that all their efforts to give their children an identity will be destroyed. It would be very harmful to the children's sense of identity .... It is a time in their lives when they cannot easily endure the rejection of their identity by an entire band." 102

The remaining portion of section 1 of the amendment protects important interests that traditionally have followed membership. That portion guarantees Native American women not only nominal membership, but also the rights and privileges that properly accompany that status.

\section{Section 2: Application and Remedy}

The two-year grace period provides Indian tribes with sufficient time to comply with the antidiscrimination policy without outside interference. This leeway allows tribes time to modify membership codes and to educate tribal judges, officials, and other members.

100. Discriminatory tribal membership ordinances are divided between those in which women lose membership for marrying outside their tribes and those like Santa Clara Pueblo's in which children of women who marry outside the tribe lose their membership. Santa Clara Pueblo v. Martinez, 436 U.S. 49, 52 n.3 (1978) (example of tribal membership ordinance).

101. The proposed amendment would have limited retroactive effect. Women and children who suffered discrimination under pre-amendment membership laws are given a right to petition the tribes for reinstatement. The amendment does not, however, allow descendants to bring post mortem petitions on behalf of these individuals. The burden that limited reinstatement would place on the tribes is minimal compared to complete retroactivity. The amendment would not implicate the Ex Post Facto Clauses of the Constitution, which apply to criminal, not civil, legislation. See GERALD GUNTHER, CONSTITUTIONAL LAW 500 (11th ed. 1985).

102. See Paul, supra note 12, at 41 (quoting Holmes). 
The federal court jurisdiction is designed to be as limited as possible while still enabling enforcement of the proposal. ${ }^{103} \mathrm{~A}$ violation of the amendment would act as a waiver of sovereign immunity, carving out an exception to the general rule set forth in Santa Clara. ${ }^{104}$ This exception would be allowed only after the exhaustion of tribal court remedies, unless the aggrieved party can show that exhaustion would be futile ${ }^{105}$ due to a history of unreasonable delays or unreasonable tribal court practices. ${ }^{106}$ Such limited judicial review responds to Native Americans' requests for "help in protecting [tribal members] from [their own] government." 107

\section{CONCLUSION}

The Santa Clara decision showed great respect for the sovereignty of Native American tribes. ${ }^{108}$ Yet in awarding such unrestricted sovereignty, the Court has left Native American women powerless within their communities. Native American women are suffering economically and psychologically because of gender discrimination within their tribes.

The Indian Civil Rights Act was designed to protect the individual rights of Native Americans. ${ }^{109}$ Hearings before the U.S. Commission on Civil Rights have shown that tribal courts are not affording this protection to the individuals within their jurisdictions. In light of the current plight of Native American women, an expansion of the ICRA is warranted. Congress has a duty to provide an enforcement mechanism for the rights enumerated in the ICRA. Without statutory gender protection such as the amendment proposed by this Note, Native American women may find themselves at the mercy of the tribes, with no avenue open to fight systematic discrimination. An amendment to the ICRA providing for specific gender protection would guarantee that tribes will treat Native American women in a fair and equitable manner.

103. The focus of this amendment is defined narrowly in order to preserve tribal powers to the fullest extent possible. The purpose of this amendment is not to destroy tribal sovereignty, but rather to guarantee American Indian women the right to participate in that sovereignty by protecting membership equality.

104. Santa Clara Pueblo v. Martinez, 436 U.S. 49 (1978) (tribes have sovereign immunity from civil suits).

105. For example, futility would be found if the woman can offer convincing proof that the lack of separation of powers makes the tribal court "a sort of "kangaroo court" " subject to control by other tribal officials. See, e.g., Little Horn State Bank v. Crow Tribal Court, 690 F. Supp. 919, 923 (D. Mont. 1988).

106. See, e.g., Hearings, supra note 46, at 71 (Sept. 29, 1989) (testimony of Judge Rousseau, SissetonWahpeton tribal judge) (referring to lack of separation of powers within tribal court system that can result in collusion by tribal officials).

107. The Indian Civil Rights Act Amendment of 1988, supra note 47, at $\$ 11,655$ (quoting letter from tribal member received Sept. 6, 1985).

108. Santa Clara Pueblo v. Martinez, 436 U.S. 49 (1978).

109. See id. at 61 (quoting S. REP. No. 841, supra note 7, at 5-6). 
